\title{
Pengaruh Promosi Dan Service Quality Terhadap Kepuasan Pelanggan Pengguna Layanan Grab-Food Pada Aplikasi Grab Di Singaraja
}

\author{
Ni Luh Saras Suratni ${ }^{* 1}$, Ni Made Dwi Ariani Mayasari² \\ 1,2Program Studi Manajemen \\ Universitas Pendidikan Ganesha \\ Singaraja, Indonesia
}

e-mail: niluhsarassuratni23@undiksha.ac.id ${ }^{* 1}$, dwi.mayasari@undiksha.ac.id²

Pengutipan: Suratni, N.L. S., Mayasari, N. M. D. A. (2021). Pengaruh Promosi Dan Service Quality Terhadap Kepuasan Pelanggan Pengguna Layanan Grabfood Pada Aplikasi Grab Di Singaraja. Jurnal Pendidikan Ekonomi Undiksha, 13(1), 50-59 http://dx.doi.org/1 0.23887/ijpe.v13i 1.32129

\begin{abstract}
Abstrak
Riwayat Artikel Tanggal diajukan: 12 Februari 2021

Tanggal diterima : 24 Mei 2021

Tanggal dipublikasikan: June 25, 2021

Penelitian ini bertujuan untuk menguji pengaruh promosi dan service quality secara simultan maupun parsial terhadap kepuasan pelanggan pengguna layanan Grab-food pada aplikasi Grab di Singaraja. Jumlah sampel dalam penelitian ini yaitu 100 responden, teknik sampel yang digunakan yaitu teknik purposive sampling. Metode pengumpulan data yang digunakan adalah kuesioner. Teknik analisis data dalam penelitian ini adalah kuantitatif dengan menggunakan analisis regresi linier berganda. Hasil dari penelitian ini menunjukkan bahwa (1) Promosi dan service quality berpengaruh positif dan signifikan secara simultan terhadap kepuasan pelanggan dengan sumbangan pengaruh sebesar $62,1 \%$ serta pengaruh variabel lain sebesar 37,9\%. (2) Promosi berpengaruh positif dan signifikan secara parsial terhadap kepuasan pelanggan dengan sumbangan pengaruh sebesar $33,6 \%$. (3) Service quality berpengaruh positif dan signifikan secara parsial terhadap kepuasan pelanggan dengan sumbangan pengaruh sebesar $11,2 \%$.
\end{abstract}

Kata kunci: kepuasan pelanggan; promosi; service quality.

Abstract
This study was aimed to examine the effect of simultaneous and partially
promotion and service quality on customer satisfaction of Grab-food service users
on the Grab application in Singaraja. The number of samples in this study were
100 respondents, the sample technique used purposive sampling. The data
method used a questionnaire. The data analysis technique in this research is
quantitative using multiple linear regression analysis. The result of the study
showed that (1) promotion and service quality has a positive and significant effect
simultaneous on customer loyalty with a contribution influence of $62.1 \%$ and other
variables was $37.9 \%$. (2) promotion has a positive and significant effect partially
on customer satisfaction with a contribution influence of 33.6\%. (3) service quality
has a positive and significant effect partially on customer satisfaction with a
contribution influence of $11.2 \%$.

Keywords: customer satisfaction; promotion; service quality.

\section{PENDAHULUAN}

Perkembangan teknologi dan informasi pada era globalisasi saat ini cenderung meningkat sangat pesat dan semakin berkembang dengan cepat sehingga mempermudah aktivitas manusia. Perkembangan teknologi informasi ditandai dengan kemunculan jaringan internet dan berbagai macam alat komunikasi seperti telephone, smartphone, laptop dan lain sebagainya. Adanya kemajuan teknologi informasi menyebabkan banyak muncul industri kreatif dan inovatif yang berbasis teknologi 
p-ISSN : 2599-1418

e-ISSN : 2599-1426

informasi. Adanya penggunaan internet dan smartphone, semua aktivitas jual beli dapat dilakukan dengan mudah dan cepat. Salah satu perangkat teknologi yang seringkali dimanfaatkan dalam industri yang berbasis teknologi informasi yaitu aplikasi (apps). Industri memanfaatkan aplikasi untuk aktivitas komunikasi, pemasaran dan membangun citra industri secara online. Saat ini, sebagian perusahaan memiliki aplikasi untuk merek dan produknya.

Pada era percepatan teknologi digital saat ini seluruh perusahaan di tuntut untuk bersaing semakin ketat. Hal ini karena teknologi digital yang berkembang dengan sangat pesat mulai digunakan sebagai salah satu strategi perusahaan untuk mengalahkan pesaing. Dengan hadirnya teknologi yang memudahkan untuk memenuhi kebutuhan. Terutama pada bisnis jasa yang saat ini berkembang bersama dengan teknologi yang semakin memudahkan untuk pencapaian kebutuhan manusia. Adapun perusahaan jasa yang memanfaatkan teknologi informasi dan internet sebagai pemasarannya yaitu Grab dan Go-Jek bisnis online berbasis aplikasi mobile smartphone yang semakin memudahkan konsumen untuk mendapatkan jasa.

Salah satu faktor keberhasilan perusahaan dalam menjalankan suatu usaha adalah dapat memberikan pelayanan yang sesuai dengan harapan konsumen sehingga konsumen merasakan kepuasan dalam menggunakan suatu jasa atau produk. Menurut Kotler and Keller (2013) kepuasan adalah perasaan senang atau kecewa seorang yang timbul dari membandingkan kinerja atau produk yang dipersepsikan atau hasil terhadap ekspektasi seseorang. Kepuasan pelanggan terhadap perusahaan jasa diartikan sebagai suatu keadaan dimana harapan konsumen terhadap suatu pelayanan sesuai dengan kenyataan yang diterima tentang pelayanan yang diberikan kepada konsumen. Jika pelayanan suatu perusahaan jasa tersebut jauh dibawah harapan konsumen maka konsumen akan merasa kecewa. Sebaliknya, jika layanan yang diberikan memenuhi harapan
Jurnal Pendidikan Ekonomi Undiksha

Vol. 13 No. 1 (2021)

konsumen maka konsumen akan merasa senang.

Sebelum memberikan kepuasan pada pelanggan perusahaan harus dikenal terlebih dahulu oleh konsumen. Perusahaan dapat dikenal oleh konsumen dengan cara melakukan promosi dalam memasarkan produk atau jasa yang ditawarkan. Promosi merupakan sarana bagi suatu perusahaan, berupa suatu kegiatan dengan tujuan menciptakan komunikasi yang terarah antara produsen dan konsumen. Sunyoto (2014) menyatakan bahwa promosi merupakan salah satu variabel dalam bauran pemasaran yang sangat penting dilaksanakan oleh perusahaan dalam kegiatan pemasaran produk atau jasa. Menurut Tjiptono (2008) promosi merupakan salah satu faktor penentu keberhasilan suatu program pemasaran tentang kualitas suatu produk atau jasa. Bila konsumen belum pernah mendengarnya dan tidak yakin akan produk itu berguna, maka konsumen tidak akan pernah membeli atau menggunakannya. Sehingga promosi sangat penting dilakukan oleh suatu perusahaan untuk memasarkan produk atau jasa yang ditawarkan.

Promosi yang baik harus diimbangi dengan kualitas pelayanan yang dapat memuaskan kebutuhan dan keinginan konsumen agar dapat menimbulkan rasa puas dalam penggunaan suatu produk atau jasa yang ditawarkan. Dalam dunia bisnis dengan situasi seperti ini, maka yang paling menentukan perusahaan agar dapat bersaing dengan yang lain adalah perusahaan yang dapat menghasilkan pelayanan yang terbaik. Oleh karena itu perusahaan harus selalu meningkatkan pelayanan kepada pelanggan dalam bentuk service quality (kualitas pelayanan). Service quality yang diberikan oleh perusahaan penyedia jasa online harus benar-benar sangat diperhatikan. Hal ini dikarenakan dengan kualitas layanan online yang baik, maka konsumen akan meningkatkan kepuasan pengguna jasanya. Menurut Tjiptono (2014) service quality (kualitas pelayanan) merupakan tingkat keunggulan (excellence) yang diharapkan dan pengendalian atas keunggulan tersebut untuk memenuhi 
p-ISSN : 2599-1418

e-ISSN : 2599-1426

keinginan pelanggan. Dengan kata lain terdapat dua faktor utama yang mempengaruhi service quality (kualitas pelayanan), layanan yang diharapkan (expected service) dan layanan yang dipersepsikan (perceived service). Service quality (kualitas pelayanan) yang baik dapat meningkatkan kepuasan pelangan menggunakan produk atau jasa merupakan suatu keberhasilan perusahaan.

Saat ini banyak perusahaan yang menerapkan promosi untuk menarik konsumen agar menggunakan produk atau jasa dan memberikan service quality untuk meciptakan kepuasan pelanggan dalam menggunakan produk atau jasa yang ditawarkan. Salah satu perusahaan yang bergerak di bidang jasa yaitu Grab merupakan perusahaan yang bergerak dibidang jasa khususnya e-commerce tentunya harus melakukan promosi dan memberikan service quality untuk memberikan kepuasan pada pelanggan. Grab merupakan salah salah satu perusahaan jasa online yang memanfaatkan kecanggihan teknologi dan internet. Berawal dari layanan transportasi, Grab kini telah mempunyai layanan lain seperti pengantaran makanan dan pembayaran yang bisa diakses lewat aplikasi mobile. Pada penelitian ini memfokuskan pada layanan jasa pesan-
Jurnal Pendidikan Ekonomi Undiksha

Vol. 13 No. 1 (2021)

antar makanan (Grab-Food) pada aplikasi Grab.

Grabfood merupakan salah satu layanan delivery makanan dan minuman yang memudahkan konsumen untuk mendapatkan makanan dan minuman yang diinginkan tanpa pergi ke resto atau lama menunggu antrian yang membuat konsumen menjadi bosan. Konsumen bisa memesan makanan yang diinginkan melalui aplikasi grab yang dapat di unduh melalui aplikasi play store untuk perangkat android dan app store untuk perangkat IOS (iPhone Operating System). Grab memiliki kekuatan untuk bersaing dalam menguasai pangsa pasar, terlebih lagi Grab berhasil mengakuisisi Uber. Keberhasilan Grab mengambil alih Uber akan menambah kekuatan Grab dalam bersaing dengan perusahaan lainnya yang sejenis karena semua armada, sumber daya manusia yang dimiliki oleh Uber bekerja untuk kepentingan Grab. Pada sektor usaha ini, yang menjadi pesaing usaha Grab-food adalah Go-food yang dianggap sebagai pioner dalam layanan jasa antar makanan, dan respon konsumen yang tinggi menyebabkan pesaing grab-food yaitu go-food memberikan layanan yang sama sebagai alternatifnya. Kedua perusahaan ini saling bersaing dalam menguasai pangsa pasar.

Tabel 1. Perkembangan Jasa Transportasi Online dari Tahun 2016-2020

\begin{tabular}{|c|c|c|}
\hline Tahun & Brand & Brand Index \\
\hline \multirow{2}{*}{2016} & Go-Jek & $80.8 \%$ \\
\hline & Grab & $14.7 \%$ \\
\hline \multirow{2}{*}{2017} & Go-Jek & $59.2 \%$ \\
\hline & Grab & $28.2 \%$ \\
\hline \multirow{3}{*}{2018} & Go-Jek & $44.9 \%$ \\
\hline & Grab & $48.0 \%$ \\
\hline & Go-Jek & $44.6 \%$ \\
\hline 2019 & Grab & $43.1 \%$ \\
\hline 2020 & $\begin{array}{l}\text { Go-Jek } \\
\text { Grab }\end{array}$ & $\begin{array}{l}47.3 \% \\
43.5 \%\end{array}$ \\
\hline
\end{tabular}

Sumber : Top Brand Index

Berdasarkan data di atas menunjukkan bahwa Grab masih menduduki peringkat kedua di bawah Gojek padahal jika dilihat dari segi promosi dan service quality Grab tidak kalah dengan Go-Jek. Selain itu jika dilihat dari data di atas Top Brand Index Grab mengalami peningkatan pada tahun 2018 dengan jumlah $48.0 \%$, sedangkan pada tahun 2019 mengalami penurunan dengan jumlah $43.1 \%$ dan pada tahun 2020 mengalami peningkatan tetapi masih 
p-ISSN : 2599-1418

e-ISSN : 2599-1426

jauh lebih kecil jika dibandingkan dengan Brand Index pada tahun 2018. Berdasarkan data di atas dapat dilihat adanya kesenjangan antara teori dengan fakta dilapangan, dimana Grab sudah memberikan promosi berupa potongan harga pada layanan Grab-Food dan melakukan promosi dengan gencar pada social media namun kepuasan pelanggan Grab mengalami penurunan.

Keadaan yang dialami oleh Grab berbanding terbalik dengan teori yang dikemukakan oleh Faradina (2016) bahwa terdapat pengaruh yang berarti antara promosi dan service quality (kualitas pelayanan) terhadap kepuasan pelanggan, artinya apabila promosi dan service quality suatu perusahaan baik maka kepuasan pelanggan akan meningkat. Grab telah melakukan promosi yang tinggi di kalangan masyarakat namun ada beberapa keluhan di kalangan masyarakat terkait dengan kualitas pelayanan Grab sehingga membuat kepuasan pelanggan ikut mengalami penurunan. Maka dari itu perlu dilakukan penelitian kembali terkait pengaruh dari ketiga variabel tersebut. Selain adanya kesenjangan antara teori dengan fakta di lapangan, penelitian ini juga perlu dilakukan karena adanya research gap dari penelitian-penelitian terdahulu. Dalam beberapa penelitian terdapat beberapa hasil penelitian terdahulu yang mengungkapkan adanya pengaruh promosi dan service quality terhadap kepuasan pelanggan namun terdapat kesenjangan dalam penelitian terkait hubungan ketiga variabel tersebut. Penelitian yang dilakukan oleh Faradina (2016) memperoleh hasil dalam penelitiannya bahwa promosi dan kepuasan pelanggan secara bersamasama berpengaruh positif dan signifikan terhadap kepuasan pelanggan. Namun berbeda dengan penelitian yang dilakukan oleh Lenzun, J. J., Massie \& Adare (2014) menyatakan bahwa promosi berpengaruh negatif dan tidak signifikan terhadap kepuasan pelanggan. Penelitian yang dilakukan oleh Nasution et al. (2018) juga menunjukkan bahwa kualitas pelayanan tidak berpengaruh secara signifikan terhadap kepuasan pelanggan. Dari adanya kesenjangan hasil penelitian dan
Jurnal Pendidikan Ekonomi Undiksha

Vol. 13 No. 1 (2021)

kesenjangan antara teori dengan fakta di lapangan yang terjadi pada Grab, sehingga perlu dilakukan penelitian untuk menguji "Pengaruh Promosi dan Service Quality Terhadap Kepuasan Pelanggan Pengguna Layanan Grab-food Pada Aplikasi Grab di Singaraja".

Adapun tujuan dari penelitian ini adalah untuk menguji pengaruh (1) Promosi dan service quality terhadap kepuasan pelanggan pengguna layanan grab-food pada aplikasi Grab di Singaraja, (2) Promosi terhadap kepuasan pelanggan pengguna layanan grab-food pada aplikasi Grab di Singaraja, dan (3) Service quality terhadap kepuasan pelanggan pengguna layanan grab-food pada aplikasi Grab di Singaraja.

\section{METODE}

Penelitian ini dilaksanakan di Singaraja. Jenis penelitian yang digunakan dalam penelitian ini adalah penelitian kuantitatif. Desain Penelitian yang digunakan dalam penelitian ini adalah kuantitatif kausal yaitu penelitian yang dilakukan untuk menguji hubungan sebab akibat yang dimana perubahan dari satu variabel menyebabkan perubahan pada variabel lain. Penelitian ini terdiri dari variabel bebas $(X)$ dan variabel terikat $(Y)$. Variabel bebas dalam penelitian ini adalah promosi $\left(\mathrm{X}_{1}\right)$ dan service quality $\left(\mathrm{X}_{2}\right)$ sedangkan variabel terikat dalam penelitian ini adalah kepuasan pelanggan (Y). Subjek dalam penelitian ini adalah konsumen yang menggunakan layanan Grab-food pada aplikasi Grab di Singaraja. Sedangkan objek penelitian ini yaitu promosi, service quality, dan kepuasan pelanggan.

Populasi adalah wilayah generalisasi yang terdiri atas, obyek atau subyek yang mempunyai kuantitas dan karakteristik tertentu yang ditetapkan oleh peneliti untuk dipelajari dan kemudian ditarik kesimpulannya Sugiyono (2017). Populasi penelitian ini yaitu konsumen yang menggunakan layanan Grab-food pada aplikasi Grab di Singaraja. Sampel adalah bagian dari jumlah karakter yang dimiliki oleh populasi tersebut (Sugiyono, 2017). Penelitian ini adalah penelitian sampel dimana pengambilan sampel menggunakan teknik purposive sampling, 
p-ISSN : 2599-1418

e-ISSN : 2599-1426

yaitu teknik penentuan sampel yang didasarkan dengan beberapa pertimbangan atau kriteria tertentu (Sugiyono, 2017). Adapun kriteria responden yang diambil sebagai sampel adalah konsumen yang menggunakan layanan Grab-food pada aplikasi Grab di Singaraja lebih dari 2 kali dalam sebulan. Banyaknya sampel dalam penelitian tergantung dari jumlah parameter yang estimasi. Augusty (2006) menyatakan bahwa banyaknya sampel dalam penelitian tergantung dari jumlah pedomannya adalah 5-10 kali jumlah indikator yang di estimasi. Dalam penelitian ini menggunakan 12 indikator sehingga banyaknya responden yang diambil sebagai sampel minimal dalam penelitian ini adalah $5 \times 12=60$ dan maksimal sampel yang bisa diambil dalam penelitian ini adalah $10 \times 12=120$. Pada penelitian ini menggunakan sampel sebanyak 100 responden untuk menghindari kurangnya response rate jika ada kuesioner yang tidak valid. Data yang dikumpulkan dalam penelitian ini adalah data interval.

Penelitian ini bertujuan untuk menguji pengaruh promosi dan service quality terhadap kepuasan pelanggan layanan Grab-food pada aplikasi Grab di Singaraja
Jurnal Pendidikan Ekonomi Undiksha

Vol. 13 No. 1 (2021)

baik secara simultan maupun secara parsial, sehingga metode yang digunakan adalah analisis regresi linier berganda dengan bantuan program Statistical Package Social Science (SPSS). Analisis regresi linier berganda melibatkan lebih dari satu variabel bebas yang digunakan untuk mengetahui pengaruh terhadap variabel terikat (Ghozali, 2018).

\section{HASIL DAN PEMBAHASAN}

Penelitian ini menggunakan analisis regresi linier berganda karena melibatkan lebih dari satu variabel bebas untuk mengetahui pengaruhnya terhadap variabel terikat. Sebelum melakukan analisis regresi linier berganda, model regresi harus memenuhi syarat asumsi klasik yang terdiri dari uji normalitas, uji multtikolonieritas, dan uji heteroskedastisitas. Berdasarkan hasil penelitian, seluruh model regresi telah memenuhi syarat asumsi klasik sehingga model regresi layak digunakan untuk memprediksi pengaruh variabel bebas terhadap variabel terikat. Hasil analisis uji regresi linier berganda yang berupa rangkuman output SPSS dapat dilihat pada Tabel 2. berikut.

Tabel 2. Hasil Pengujian Regresi Linier Beganda

\begin{tabular}{|c|c|c|c|c|c|}
\hline Parameter & Nilai & $\begin{array}{c}P- \\
\text { Value }\end{array}$ & $\begin{array}{l}\text { Alpha } \\
(\alpha)\end{array}$ & Keputusan & Simpulan \\
\hline $\begin{array}{l}F_{\text {hitung }}> \\
F_{\text {tabekl }}\end{array}$ & $\begin{array}{c}79,545> \\
3,09\end{array}$ & 0,000 & 0,05 & $\begin{array}{c}\text { Menolak } \\
\text { Ho }\end{array}$ & $\begin{array}{l}\text { Ada pengaruh simultan dari } \\
\text { promosi dan service quality } \\
\text { terhadap kepuasa pelanggan. }\end{array}$ \\
\hline $\mathrm{R}^{2}$ & 0,621 & - & - & & $\begin{array}{l}\text { Menunjukkan variabel kepuasan } \\
\text { pelanggan dapat dijelaskan dan } \\
\text { diterangkan dari kedua variabel } \\
\text { bebas yaitu promosi dan service } \\
\text { quality. }\end{array}$ \\
\hline$\varepsilon$ & 0,379 & & - & - & $\begin{array}{l}\text { Menunjukkan sebesar } 37,9 \% \\
\text { variabel kepuasan pelanggan } \\
\text { dijelaskan dan diterangkan oleh } \\
\text { variabel lain. }\end{array}$ \\
\hline $\operatorname{PyX}_{1}$ & 0,580 & 0,000 & 0,05 & $\begin{array}{c}\text { Menolak } \\
\text { Ho }\end{array}$ & $\begin{array}{l}\text { Ada pengaruh parsial dari } \\
\text { promosi terhadap kepuasan } \\
\text { pelanggan. }\end{array}$ \\
\hline$P^{2} y X_{1}$ & 0.336 & - & - & - & $\begin{array}{l}\text { Menunjukkan besarnya } \\
\text { sumbangan pengaruh parsial } \\
\text { dari promosi terhadap kepuasan } \\
\text { pelanggan yaitu sebesar } 33,6 \% \text {. }\end{array}$ \\
\hline
\end{tabular}




\begin{tabular}{|c|c|c|c|c|c|}
\hline $\mathrm{PyX}_{2}$ & 0,335 & 0,000 & 0,05 & $\begin{array}{c}\text { Menolak } \\
\text { Ho }\end{array}$ & $\begin{array}{l}\text { Ada pengaruh parsial dari } \\
\text { service quality terhadap }\end{array}$ \\
\hline$P^{2} y X_{2}$ & 0,112 & - & - & - & $\begin{array}{l}\text { kepuasan pelanggan. } \\
\text { Menunjukkan besarnya } \\
\text { sumbangan pengaruh parsial } \\
\text { dari service quality terhadap } \\
\text { kepuasan pelanggan yaitu } \\
\text { sebesar } 11.2 \% \text {. }\end{array}$ \\
\hline$\alpha$ & 1,118 & 0,000 & 0,05 & Signifikan & $\begin{array}{l}\text { Dapat memprediksi } \\
\text { kepuasan pelanggan. }\end{array}$ \\
\hline$\beta_{1}$ & 0,596 & 0,000 & 0,05 & Signifikan & $\begin{array}{l}\text { Dapat memprediksi } \\
\text { kepuasan pelanggan. }\end{array}$ \\
\hline$\beta_{2}$ & 0,286 & 0,000 & 0,05 & Signifikan & $\begin{array}{l}\text { Dapat memprediksi } \\
\text { kepuasan pelanggan. }\end{array}$ \\
\hline
\end{tabular}

Sumber : Hasil output spss analisis regresi linier berganda

Berdasarkan rangkuman hasil analisis regresi linier berganda di atas maka diperoleh struktur hubungan antar variabel promosi, service quality dan kepuasan pelanggan sebagai berikut.

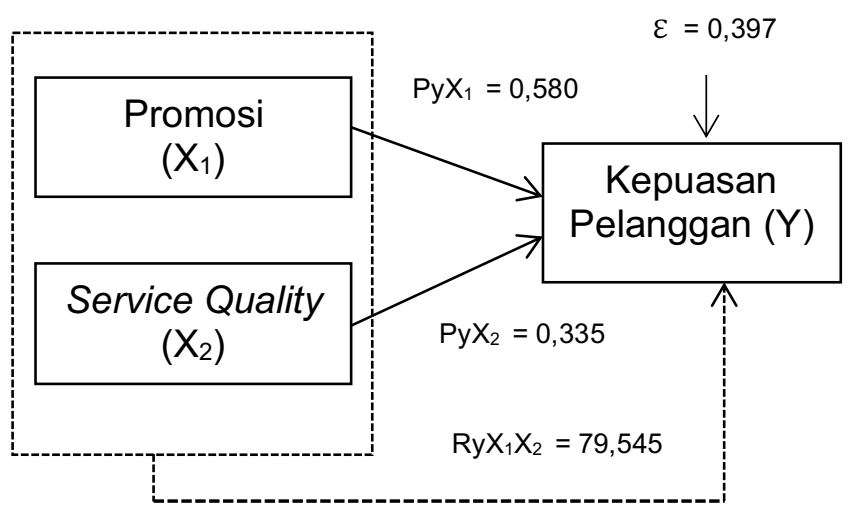

Keterangan :

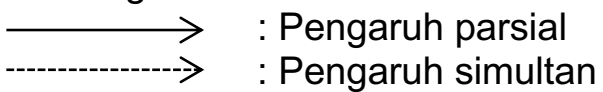

Gambar 1. Struktur Hubungan Pengaruh

Promosi dan Service Quality terhadap Kepuasan Pelanggan Pengguna Layanan Grab-food Pada Aplikasi Grab di Singaraja.

Berdasarkan hasil analisis regresi linier berganda dan struktur hubungan di atas, maka diperoleh persamaan regresi sebagai berikut.

$\hat{Y}=1,118+0,596 X_{1}+0,286 X_{2}+0,379 \varepsilon$

Dari persamaan linier berganda tersebut menunjukkan bahwa:
1) Konstanta sebesar 1,118, artinya bahwa apabila promosi $\left(\mathrm{X}_{1}\right)$ dan service quality $\left(\mathrm{X}_{2}\right)$, nilainya sama dengan nol, maka kepuasan pelanggan Grab-food (Y) sebesar $1,118$.

2) Nilai koefisien promosi $\left(\beta_{1}\right)$ sebesar 0,596 berarti bahwa promosi $\left(X_{1}\right)$ berpengaruh positif terhadap kepuasan pelanggan Grab-food (Y). Hal ini mengandung arti bahwa setiap kenaikan promosi satu satuan maka variabel kepuasan pelanggan Grabfood meningkat sebesar 0,596 sehingga menjadi $1,714(1,118+$ $0,596)$, dengan asumsi bahwa variabel bebas yang lainnya tetap.

3) Nilai koefisien service quality $\left(\beta_{2}\right)$ sebesar 0,286 berarti bahwa service quality berpengaruh positif terhadap kepuasan pelanggan ( $Y$ ). Hal ini mengandung arti bahwa setiap kenaikan service quality satu satuan maka variabel kepuasan pelanggan Grab-food meningkat sebesar 0,286 sehingga menjadi 1,404 (1,118 + $0,286)$, dengan asumsi bahwa variabel bebas yang lainnya tetap.

Berdasarkan rekapan hasil uji regresi linier berganda pada Tabel 2 . menunjukan hasil $\mathrm{RyX}_{1} \mathrm{X}_{2}=79,545$,

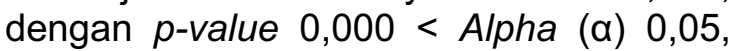
yang menyatakan bahwa menolak Ho yang berarti ada pengaruh positif dan signifikan dari promosi $\left(\mathrm{X}_{1}\right)$ dan service quality $\left(\mathrm{X}_{2}\right)$ terhadap kepuasan pelanggan Grab-food (Y), dengan sumbangan pengaruh sebesar $62,1 \%$. Hasil tersebut 
p-ISSN : 2599-1418

e-ISSN : 2599-1426

menunjukan bahwa sebesar $62,1 \%$ kepuasan pelanggan $(\mathrm{Y})$ dipengaruhi oleh promosi $\left(\mathrm{X}_{1}\right)$ dan service quality $\left(\mathrm{X}_{2}\right)$. Sedangkan sisanya sebesar $37,9 \%$ dipengaruhi oleh variabel lainnya. Hal ini dapat disimpukan bahwa variabel promosi $\left(X_{1}\right)$ dan service quality $\left(X_{2}\right)$ secara bersama-sama berperan dalam meningkatkan kepuasan pelanggan Grabfood $(\mathrm{Y})$.

Berdasarkan rekapan hasil uji regresi linier berganda pada Tabel 2 . menunjukan hasil $\mathrm{PyX}_{1}=0,580$ dengan $p$ value $0,000<$ Alpha (a) 0,05 hal ini menyatakan bahwa menolak Ho yang berarti ada pengaruh positif dan signifikan dari promosi $\left(\mathrm{X}_{1}\right)$ terhadap kepuasan pelanggan $(Y)$, dengan sumbangan pengaruh sebesar 0,336 atau $33,6 \%$. Hal ini dapat disimpukan bahwa variabel promosi berperan dalam meningkatkan.

Berdasarkan rekapan hasil uji regresi linier berganda pada Tabel 2 . menunjukan hasil $\mathrm{PyX}_{2}=0,345$ dengan $p$ value $0,000<$ Alpha (a) 0,05 hal ini menyatakan bahwa menolak Ho yang berarti ada pengaruh positif dan signifikan dari service quality $\left(\mathrm{X}_{2}\right)$ terhadap kepuasan pelanggan Grab-food (Y), dengan sumbangan pengaruh sebesar 0,112 atau $11,2 \%$. Hal ini dapat disimpukan bahwa variabel service quality berperan dalam meningkatkan kepuasan pelanggan pengguna layanan grab-food.

\section{Pengaruh Promosi dan Service Quality terhadap Kepuasan Pelanggan}

Promosi dan service quality berperngaruh signifikan terhadap kepuasan pelanggan pengguna layanan grab-food pada aplikasi Grab di Singaraja. Promosi dan service quality sangat berpengaruh terhadap kepuasan pelanggan. Faradina (2016) menyatakan bahwa pengaruh dari promosi serta kualitas pelayanan yang di berikan konsumen dapat menarik kedatangan konsumen sehingga dapat serta menjadi daya tarik tersendiri bagi konsumen yang lama menjadi pelanggan tetap GrabFood, maka itu merupakan salah satu penilaian terhadap kepuasan konsumen dengan standar kenyamanan konsumen karena
Jurnal Pendidikan Ekonomi Undiksha

Vol. 13 No. 1 (2021)

sesuai dengan harapan yang diinginkan. Ketika suatu perusahaan sudah melakukan promosi yang baik tetapi jika tidak memberikan service quality yang baik maka tidak akan terciptanya kepuasan pelanggan dalam penggunaan suatu jasa tersebut. Sehingga dengan memperhatikan promosi dan kualitas pelayanan secara bersamaan akan meningkatkan kepuasan pelanggan layanan GrabFood lebih baik dibandingkan hanya dengan fokus kepada salah satunya. Hal ini dapat dilihat dari besar pengaruh dari promosi dan kualitas pelayanan yang tinggi.

Hal tersebut sejalan dengan penelitian yang dilakukan oleh Pratamayudha et al. (2018) yang yang menyatakan promosi dan service quality berpengaruh secara signifikan terhadap kepuasan pelanggan. Vallery, Happy Novita (2019) dalam penelitiannya juga menyatakan bahwa terdapat pengaruh yang positif dan signifikan antara promosi dan service quality terhadap kepuasan pelanggan. Semakin baik promosi dan service quality yang diberikan, maka akan semakin tinggi pula kepuasan pelanggan yang dirasakan dalam menggunakan suatu jasa yang ditawarkan oleh GrabFood Singaraja. Sebaliknya, apabila promosi dan service quality yang diberikan kurang baik, maka akan semakin menurun pula kepuasan pelanggannya. Maka dari itu pihak GrabFood perlu melakukan promosi yang lebih gencar agar nama GrabFood tertanam dibenak masyarakat dan mengalahkan pesaing-pesaing yang ada. Selain itu GrabFood juga perlu meningkatkan kualitas pelayanan dari segi pengantaran dan keramah tamahan dari para driver sehingga akan semakin tinggi tingkat kepuasan pelanggan.

\section{Pengaruh Promosi terhadap Kepuasan Pelanggan}

Promosi berperngaruh positif dan signifikan terhadap Kepuasan Pelanggan pengguna layanan grab-food pada aplikasi Grab di Singaraja. Promosi sangat berperan penting dalam bauran pemasaran yang dapat digunakan perusahaan untuk meningkatkan penjualan produk atau jasa yang menghasilkan keuntungan bagi 
p-ISSN : 2599-1418

e-ISSN : 2599-1426

perusahaan. Promosi penjualan adalah rangsangan langsung yang ditujukan kepada konsumen untuk melakukan pembelian yang dapat menarik konsumen untuk mencoba suatu produk baru, sehingga dapat meningkatkan penjualan. Dengan adanya promosi penjualan yang dilakukan oleh GrabFood Singaraja, konsumen mejadi lebih tertarik untuk menggunakan fasilitas yang ditawarkan, maka dari itu perusahaan harus dapat terus berinovasi untuk meningkatkan kepuasan pelanggan.

Jika tanpa adanya promosi maka keberadaan perusahaan kurang mendapat perhatian dari masyarakat atau bahkan konsumen tidak tahu sama sekali mengenai produk atau jasa yang ditawarkan. Uraian tersebut sesuai dengan pengertian Djaslim (2003) yaitu suatu komunikasi informasi penjual dan pembeli yang bertujuan, yang tidak mengenal menjadi mengenal sehingga menjadi pembeli dan tetap mengingat produk tersebut. Menurut Buchari (2011), tujuan promosi penjualan untuk menarik konsumen baru dan meningkatkan kepuasan bagi pelanggan. Hal ini sesuai dengan penelitian dari Dewa (2018) dan Gulla, R., Oroh \& Roring (2015) yang menyatakan variabel promosi mempunyai pengaruh signifikan terhadap kepuasan pelanggan.

Sehingga sangat penting bagi GrabFood untuk memperhatikan strategi promosi yang digunakan baik dari pemberian diskon, gratis ongkir ataupun strategi promosi yang lain, agar benarbenar dapat memberikan kepuasan kepada pelanggan. Mengingat pelanggan GrabFood didominasi oleh anak muda, maka GrabFood harus menyesuaikan promosinya dengan mayoritas pelanggannya. Misalnya, memberikan diskon pada restoran tertentu yang menyediakan makanan dan minuman paling banyak digemari dikalangan anak muda.

\section{Pengaruh Service Quality terhadap Kepuasan Pelanggan \\ Service quality berperngaruh positif dan signifikan terhadap kepuasan pelanggan pengguna layanan grab-food pada aplikasi Grab di Singaraja. Sercive}

Jurnal Pendidikan Ekonomi Undiksha

Vol. 13 No. 1 (2021)

quality (kualitas pelayanan) perusahaan dianggap baik dan memuaskan jika perusahaan dapat memberikan jasa melampaui harapan konsumen, jika jasa yang diberikan lebih rendah daripada harapan konsumen, maka kualitas pelayanan perusahaan dianggap buruk. Pelayanan yang bertaraf tinggi akan menghasilkan kepuasan yang tinggi serta pembelian ulang yang lebih sering (Tjiptono, 2008). Kualitas pelayanan memiliki dampak yang besar terhadap kepuasan pelanggan. Terciptanya kepuasan pelanggan dapat memberikan beberapa manfaat, diantaranya hubungan yang baik antara perusahaan dan pelanggan menjadi harmonis, hubungan yang baik ini memungkinkan perusahaan untuk memahami dengan seksama harapan pelanggan serta kebutuhan yang diinginkan sehingga dapat meningkatkan kepuasan kepada pelanggan, memberikan dasar yang baik bagi pembelian ulang dan terciptanya kepuasan pelanggan, dan membentuk suatu rekomendasi dari mulut ke mulut (word of mouth) yang dapat menguntungkan bagi perusahaan (Tjiptono, 1997). Hal ini sejalan dengan penelitian yang dilakukan oleh Vallery, Happy Novita (2019), dan Haryanto (2013) yang menyatakan bahwa service quality berpengaruh positif signifikan terhadap kepuasan pelanggan. Saat ini sangat banyak terdapat penyedia jasa pengantaran makanan atau minuman, sehingga pesaing GrabFood juga semakin banyak. GrabFood harus dapat memberikan kesan yang berbeda dibenak pelanggan agar pelanggan selalu menggunakan jasa GrabFood.

Hal tersebut dapat dilakukan dengan memberikan pelayanan yang lebih baik dari pesaing-pesaing yang ada, sehingga pelanggan akan merasa puas dan enggan untuk berpindah ke penyedia jasa lainnya. Misalnya, dalam kaitannya dengan reliability (keandalan) driver dalam melayani pelanggan dirasa sudah cukup baik, perusahaan harus mampu mempertahankan jika perlu lebih ditingkatkan lagi. Dalam kaitannya dengan responsiveness (daya tanggap) yang diberikan oleh driver perlu untuk ditingkatkan, upaya ini dapat dilakukan dengan cara driver GrabFood harus cepat 
p-ISSN : 2599-1418

e-ISSN : 2599-1426

tanggap terhadap keinginan pelanggan yaitu harus adanya driver yang tersedia disetiap saat, karena kadang ketika pemesanan makanan pelanggan lama dalam mendapatkan driver. Dalam kaitannya dengan assurance (jaminan dan kepastian), GrabFood perlu meningkatkan jaminan yang menjadi salah satu faktor penting yang berpengaruh terhadap kepuasan pelanggan. Jaminan yang diberikan oleh GrabFood dapat dilakukan dengan mengantarkan makanan secara cepat dan aman sampai ke pelanggan. Selain itu banyak driver yang mengantarkan pesanan ke lokasi yang salah sehingga pengetahuan driver dalam hal pencarian lokasi perlu di tingkatkan. Dalam kaitannya dengan emphaty (kepedulian) hal ini harus dipertahankan dan ditingkatkan dengan cara driver harus lebih peka terhadap keinginan dan kebutuhan pelanggan, serta mengembangkan kemampuan berkomunikasi antara driver dengan pelanggan agar pelanggan merasa nyaman dan puas menggunakan jasa GrabFood, dan adanya keinginan untuk kembali menggunakan jasa GrabFood. Dalam kaitannya dengan tangible (wujud fisik), penampilan driver yang bersih dan rapi juga sangat mempengaruhi kepuasan pelanggan, oleh karena itu driver harus mempertahankan penampilan yang digunakan agar tetap terlihat bersih dan rapi.

\section{SIMPULAN DAN SARAN}

Penelitian ini didasari oleh menurunnya brand index Grab pada tahun 2019 dan kedudukan Grab yang masih menduduki posisi ke 2 pada Top Brand Index. Jika dilihat dari data Top Brand Index Grab mengalami peningkatan pada tahun 2018 dengan jumlah 48.0\%, sedangkan pada tahun 2019 mengalami penurunan dengan jumlah $43.1 \%$, jumlah perbandingan penurunan Grab dari tahun 2018 ke 2019 yaitu sebesar 4,9\% dan pada tahun 2020 mengalami peningkatan tetapi masih jauh lebih kecil jika dibandingkan dengan Brand Index pada tahun 2018. Grab masih menduduki peringkat kedua di bawah Gojek padahal jika dilihat dari segi promosi dan service
Jurnal Pendidikan Ekonomi Undiksha

Vol. 13 No. 1 (2021)

quality Grab tidak kalah dengan Go-Jek. Selain itu, adanya kesenjangan antara teori dengan fakta dilapangan, dimana Grab sudah memberikan promosi berupa potongan harga atau diskon pada layanan Grab-Food dan melakukan promosi dengan gencar pada social media namun kepuasan pelanggan Grab mengalami penurunan.

Berdasarkan hasil dan pembahasan yang dilakukan, maka dapat ditarik kesimpulan dalam penelitian ini sebagai berikut: (1) Promosi dan service quality berpengaruh positif dan signifikan secara simultan terhadap kepuasan pelanggan pengguna layanan grab-food pada aplikasi Grab di Singaraja. Hal ini menunjukkan bahwa semakin besar tingkat promosi dan service quality yang dapat diberikan oleh suatu perusahaan maka akan semakin besar pula tingkat kepuasan pelanggan. (2) Promosi berpengaruh positif dan signifikan secara parsial terhadap kepuasan pelanggan pengguna layanan grab-food pada aplikasi Grab di Singaraja. Hal ini menunjukkan bahwa semakin menarik promosi yang diberikan oleh perusahaan terhadap produk atau jasa perusahaan maka akan semakin besar tingkat kepuasan pelanggan. (3) Service quality berpengaruh positif dan signifikan secara parsial terhadap kepuasan pelanggan pengguna layanan grab-food pada aplikasi Grab di Singaraja. Hal ini menunjukkan bahwa semakin baik service quality yang diberikan oleh perusahaan terhadap produk atau jasa perusahaan maka akan semakin besar tingkat kepuasan pelanggan.

Berdasarkan hasil analisis, pembahasan serta beberapa simpulan pada penelitian ini, maka dapat ditarik simpulan dalam penelitian ini agar mendapat hasil yang lebih baik yaitu, sebagai berikut. (1) Bagi peneliti diharapkan agar selanjutnya dapat mengembangkan penelitian ini dengan menambahkan variabel-variabel lain yang memengaruhi kepuasan pelanggan dan dapat memperbanyak teori tentang variabel yang digunakan serta dapat menggunakan teknik analisis data yang lain agar menjadi acuan dari penelitianpenelitian selanjutnya dan dapat menambah wawasan keilmuan khususnya 
p-ISSN : 2599-1418

e-ISSN : 2599-1426

dalam Manajemen Pemasaran. (2) Bagi pihak Grab diharapkan dapat mengembangkan berbagai strategi dalam meningkatkan promosi dan service quality agar terwujudnya kepuasan pelanggan. Sehingga pada tahun berikutnya Brand Index Grab dapat kembali mengalami peningkatan dan Grab semakin dikenal dikalangan masyarakat yang gemar berbelanja makanan secara delivery melalui aplikasi Grab-food. (3) Bagi peneliti diharapkan agar selanjutnya dapat mengembangkan penelitian ini dengan menambahkan variabel-variabel lain yang memengaruhi loyalitas pelanggan dan dapat memperbanyak teori tentang variabel yang digunakan serta dapat menggunakan teknik analisis data yang lain agar dapat menjadi acuan dari penelitian-penelitian selanjutnya dan dapat menambah wawasan keilmuan khususnya dalam Manajemen Pemasaran. (4) Bagi pihak Tokopedia diharapkan dapat mengembangkan berbagai strategi dalam meningkatkan kepercayaan dan kepuasan pelanggan agar terwujudnya loyalitas pelanggan. Sehingga pada tahun berikutnya brand index Tokopedia dapat kembali mengalami peningkatan dan Tokopedia semakin dipercaya dikalangan masyarakat yang gemar berbelanja melalui e-commerce.

\section{DAFTAR PUSTAKA}

Augusty, F. (2006). Metode Penelitian Manajemen. Semarang: Badan Penerbit Universitas Diponegoro.

Buchari, A. (2011). Manajemen Pemasaran Dan Pemasaran Jasa. Bandung: Alfabeta.

Dewa, C. B. (2018). Pengaruh Kualitas Pelayanan Dan Promosi Penjualan Jasa Grab-Car Terhadap Kepuasan Pelanggan (Studi Kasus Pada Wisatawan Di Yogyakarta). Jurnal Perspektif, 16(1).

Djaslim, S. (2003). Manajemen Pemasaran, Analisis Perencanaan Pelaksanaan dan Pengendalian. Bandung: Linda Karya.

Faradina, A. (2016). Pengaruh Promosi dan Kualitas Pelayanan Terhadap Kepuasan Pelanggan pada Rumah Cantik Almanda. 5, 1-18.

Ghozali, I. (2018). Aplikasi Analisis
Jurnal Pendidikan Ekonomi Undiksha

Vol. 13 No. 1 (2021)

Multivariate Dengan Program IBM SPSS 25. Semarang: Badan Penerbit Universitas Diponegoro.

Gulla, R., Oroh, S. G., \& Roring, F. (2015). Analisis Harga, Promosi, Dan Kualitas Pelayanan Terhadap Kepuasan Konsumen Pada Hotel Manado Grace Inn. 3(1), 1313-1322.

Haryanto, R. A. (2013). Strategi Promosi, Kualitas Produk, Kualitas Layanan Terhadap Kepuasan Pelanggan Pada Restoran Mcdonald Manado. Jurnal Riset Ekonomi, Manajemen, Bisnis Dan Akuntansi, 1(4), 1465-1473.

Kotler, P., \& Keller, K. L. (2013). Manajemen Pemasaran, Jilid Kedua. Jakarta: Erlangga.

Lenzun, J. J., Massie, J. D., \& Adare, D. (2014). Pengaruh Kualitas Produk, Harga dan Promosi terhadap Kepuasan Pelanggan Kartu Prabayar Telkomsel. Jurnal EMBA, 1(3), 12371245.

Nasution, H., Maksum, C., Pascasarjana, S., \& Pancasila, U. (2018). Pengaruh Kualitas Pelayanan Dan Harga terhadap Keputusan Pembelian Customer Serta Dampaknya pada Kepuasan Pelanggan (Studi Kasus: Maskapai PT. Lion Air Jakarta). 3(2), 175-191.

Pratamayudha, S. A., Arifin, R., \& Hufron, M. (2018). Pengaruh Kemudahan Penggunaan, Kualitas Pelayanan, Harga Dan Promosi Tehadap Kepuasaan Pelanggan Grabfood. Jurnal Riset Manajemen, 77-90.

Sugiyono. (2017). Metode Penelitian Kuantitatif, Kualitatif dan R\&D. bandung: Alfabeta.

Sunyoto, D. (2014). Konsep Dasar Riset Pemasaran Dan Perilaku Konsumen. Yogyakarta: Caps.

Tjiptono, F. (1997). Prinsip-prinsip Total Quality Service. Yogyakarta: Andi.

Tjiptono, F. (2008). Strategi Pemasaran. Edisi 3. Yogyakarto: Andi.

Tjiptono, F. (2014). Pemasaran Jasa Prinsip, Penerapan Dan Penelitian. Yogyakarta: Andi Offset.

Vallery, Happy Novita, S. S. (2019). Jurnal Mantik. Jurnal Mantik, 3(1) 31-38. 